\title{
A new surface accumulation map for western Dronning Maud Land, Antarctica, from interpolation of point measurements
}

\author{
Gerit ROTSCHKY, ${ }^{1}$ Per HOLMLUND, ${ }^{2}$ Elisabeth ISAKSSON, ${ }^{3}$ Robert MULVANEY, ${ }^{4}$ \\ Hans OERTER, ${ }^{1}$ Michiel R. VAN DEN BROEKE, ${ }^{5}$ Jan-Gunnar WINTHER ${ }^{3}$
}

\author{
${ }^{1}$ Alfred Wegener Institute for Polar and Marine Research, PO Box 120161, D-27515 Bremerhaven, Germany \\ E-mail: grotschky@awi-bremerhaven.de \\ ${ }^{2}$ Department of Physical Geography, Stockholm University, SE-106 91 Stockholm, Sweden \\ ${ }^{3}$ Norwegian Polar Institute, Polar Environmental Centre, NO-9296 Tromsø, Norway \\ ${ }^{4}$ British Antarctic Survey, Natural Environment Research Council, Madingley Road, Cambridge CB3 OET, UK \\ ${ }^{5}$ Institute for Marine and Atmospheric Research Utrecht, Utrecht University, Princetonplein 5, \\ 3584 CC Utrecht, The Netherlands
}

\begin{abstract}
As a result of intensive field activities carried out by several nations over the past $\mathbf{1 5}$ years, a set of accumulation measurements for western Dronning Maud Land, Antarctica, was collected, based on firn-core drilling and snow-pit sampling. This new information was supplemented by earlier data taken from the literature, resulting in 111 accumulation values. Using Geographical Information Systems software, a first region-wide mean annual snow-accumulation field was derived. In order to define suitable interpolation criteria, the accumulation records were analyzed with respect to their spatial autocorrelation and statistical properties. The resulting accumulation pattern resembles wellknown characteristics such as a relatively wet coastal area with a sharp transition to the dry interior, but also reveals complex topographic effects. Furthermore, this work identifies new high-return shallowdrilling sites by uncovering areas of insufficient sampling density.
\end{abstract}

\section{INTRODUCTION}

Over the past few decades much effort has been put into recovering possible changes in the mass budget and dynamics of polar ice sheets in response to climate change. Mass-balance estimates, which still suffer from large uncertainties, require knowledge of the amount and spatial distribution of snow accumulation. Traditionally, shallow firn and ice cores, supplemented by snow pits, are used to derive the accumulation and climate history throughout the past few centuries. Resulting from variability in precipitation and wind-driven redistribution of snow, surface accumulation rate is highly variable spatially and temporally. Local values depend on the overall climate, regional weather conditions and terrain characteristics at macro- to microscale. For example, in accumulation averages for 4-7 years, Reijmer and Van den Broeke (2003) found standard deviations to range from $20 \%$ to $70 \%$ of the average annual accumulation, based on data from several automatic weather stations in Dronning Maud Land (DML), Antarctica. On an annual scale, large variability in accumulation has been observed from stake measurements by Melvold and others (1998), reaching up to $500 \mathrm{~kg} \mathrm{~m}^{-2} \mathrm{a}^{-1}$ over a distance of $<3 \mathrm{~km}$ on Jutulstraumen, DML. In this respect ice cores serve as a useful tool because they provide long-term averaged accumulation rates which more likely represent a typical value for their surrounding area. However, due to the time-consuming and often costly procedure of firn-core drilling, their numbers remain limited.

Sampling density of accumulation records varies strongly over the Antarctic ice sheet (Vaughan and others, 1999). Drilling sites are usually concentrated along traverse routes and easily accessible coastal regions. The sparse and uneven data distribution sets high demands on interpolation techniques used to map the broad-scale accumulation distribution over wider regions. Furthermore it is questionable whether firn-core records covering different accumulation periods can be combined in a single map if trends in accumulation history cannot be precluded. Nevertheless, for most regions, firn cores still represent the best in situ source of information that can be used for accumulation compilations.

DML has been under investigation by several countries over the past 50 years, resulting in a large body of available data. This region is particularly interesting because of its sensitivity to conditions over the Atlantic sector of the Southern Ocean, possibly connecting it with the climate record of the Greenland ice sheet. Field activities increased in the 1990s in two regards: (i) within the framework of the International Trans-Antarctic Scientific Expedition (ITASE), established in order to gain a greater understanding of Southern Hemisphere climate within the past 200 years; and (ii) as a result of pre-site surveys for the European Project for Ice Coring in Antarctica (EPICA), aimed at locating a suitable deep ice-core drilling site in the Atlantic sector of East Antarctica.

As more data on accumulation rates have been compiled successively each season, it becomes necessary to summarize and combine the information for a region-wide picture and estimation of snow accumulation in DML. To date, there is no accumulation map specifically for western DML that is based entirely on in situ data. In this paper, we present a complete set of reliable accumulation records available at the time of this study for the western DML region. For spatial interpolation we apply algorithms based on geostatistical methods and exploratory data analysis. In doing so, we aim to recover the large-scale accumulation pattern resulting from overall climate, weather and topographic conditions. Clearly, small-scale variations in accumulation cannot be resolved using point data. We discuss that dataset in terms of 


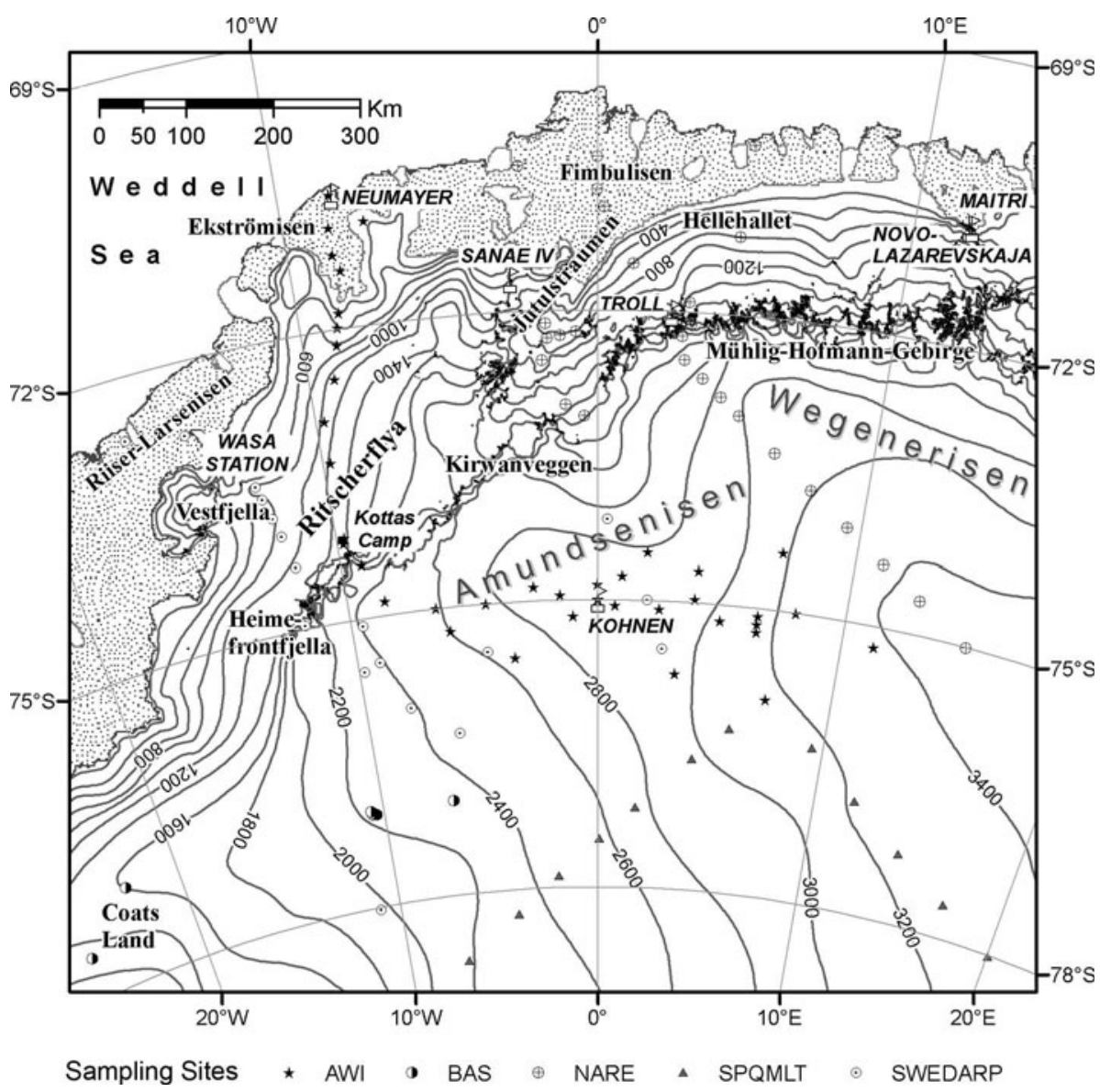

Fig. 1. Area of investigation and sampling network. Varying symbols for point records were chosen in order to distinguish between different institutions involved in data acquisition. Elevation contours in $200 \mathrm{~m}$ intervals are shown as solid black lines.

its spatial and temporal validity, justifying the combination of unevenly distributed field data representing a variety of accumulation periods at each location.

\section{GEOGRAPHICAL DESCRIPTION OF WESTERN DML}

\subsection{Morphology}

The area of investigation stretches inland from the Antarctic coast at $70^{\circ} \mathrm{S}$ to about $80^{\circ} \mathrm{S}$, bounded by the $20^{\circ} \mathrm{W}$ and $15^{\circ} \mathrm{E}$ meridians (Fig. 1). Based on its topography, western DML can be subdivided into four regions, three of which are: (1) the major ice shelves Riiser-Larsenisen, Ekströmisen and Fimbulisen; (2) the lower inland ice regions Ritscherflya and Hellehallet; and (3) the high-altitude plateau area with an elevation $>2500 \mathrm{~m}$ a.s.l., i.e. the Wegener Inlandeis made up by Amundsenisen and Wegenerisen. A clear borderline between coastal/lower inland ice regions and the plateau consists of (4) the nunatak areas of the Heimefrontfjella, Kirwanveggen and Mühlig-Hofmann-Gebirge mountain ranges, which penetrate the ice sheet, reaching heights of about $2700 \mathrm{~m}$ a.s.l. Acting as a barrier to air masses approaching from the Weddell Sea and the Atlantic Ocean to the north, this chain of mountains has a large impact on the accumulation distribution, separating the area into two distinct accumulation regimes.

The surface topography of the plateau is smooth, with wind-shaped features, i.e. small-size sastrugi $(10-15 \mathrm{~cm}$ high) (Stenberg and others, 1998), indicating that the mean wind velocities in this part of Antarctica are moderate. Undulations with amplitudes on the metre scale and wavelengths on the kilometre scale have been linked to bedrock morphology (e.g. Budd and Carter, 1971; Rotschky and others, 2004). Large areas of Amundsenisen have been delineated as ice drainage basins feeding the Filchner Ice Shelf with the ice divide as far north as $75^{\circ} \mathrm{S}$ (Giovinetto and Bentley, 1985). Major outlets from Amundsenisen are Stancomb-Wills Ice Stream, draining into the Brunt Ice Shelf, and Jutulstraumen, feeding Fimbulisen. With an area of approximately $124000 \mathrm{~km}^{2}$, Jutulstraumen is the largest ice stream within our area of investigation. Topography varies to a greater degree coastward of the nunataks, where drainage basins alternate with mountain ridges. Varying slope gradients and aspects as well as a variable surface-wind field introduce complex patterns in the accumulation distribution (Van den Broeke and others, 1999).

\subsection{General characteristics of snow accumulation}

DML is situated in the Atlantic sector of Antarctica, and in the sphere of influence of cyclonic systems that move along the coast; the strongest winds blow from the east to northeast (Lunde, 1961). Field observations reveal a typical continental precipitation distribution with a general decrease in accumulation with increasing elevation and distance from the open ocean, and with decreasing mean annual air temperature (Giovinetto and others, 1990; Vaughan and others, 1999). In DML, the nunataks interrupt this steady modification by forcing the humid air masses to rise, 
resulting in accumulation extremes of up to $780 \mathrm{~kg} \mathrm{~m}^{-2} \mathrm{a}^{-1}$ on Jutulstraumen, as reported by Melvold and others (1998) based on stake measurements over a 1 year period. Large regional variations in accumulation occur depending on predominant cyclone pathways, topographic disturbances and katabatic wind activity (Richardson and Holmlund, 1999; Van den Broeke and others, 1999; King and others, 2004). A detailed discussion of precipitation and related snow accumulation characteristics in DML was presented by Noone and others (1999).

\section{SAMPLING FRAMEWORK}

Our dataset includes accumulation data from snow-pit studies as well as from firn- and ice-core drillings carried out by six nations during 20 different Antarctic field campaigns, held over a period of about four decades. Compiled records and their sources are listed in the Appendix, tabulated by site name, campaign name and year of observation. Because of the susceptibility to errors we did not consider records based on snow-pit stratigraphy alone. Results from this method have been criticized as being generally unreliable due to subjective interpretation. Total obliteration of the annual layering, resulting from strong metamorphism or wind erosion, is considered responsible for the usual overestimations of accumulation rates derived from firn stratigraphy, particularly where accumulation is low (e.g. Picciotto and others, 1971; Giovinetto and Zwally, 2000; Frezzotti and others, 2004).

Sporadic visits to DML began with the NorwegianBritish-Swedish Antarctic Expedition in the years 1949-52; however, systematic accumulation data acquisition did not start until the late 1960s. The earliest reliable dataset originates from the third leg of the US South Pole-Queen Maud Land traverse (SPQMLT 1964-68) covering the southernmost part of the area of interest between $75^{\circ} \mathrm{S}$ and $80^{\circ} \mathrm{S}$ and between $10^{\circ} \mathrm{W}$ and $40^{\circ} \mathrm{E}$ on Amundsenisen (Picciotto and others, 1971). Here the dating of 17 snow pits was based on total $\beta$ activity deposited as a result of nuclear weapon tests. Data acquisition continued with German activities resulting in nine firn cores drilled within two seasons (1981/82 and 1986/87) at locations near the Georg von Neumayer station on Ekströmisen (Schlosser and others, 1999) and on Ritscherflya (Oerter and others, 1999). Glaciological work conducted in the framework of the Swedish Antarctic Research Program (SWEDARP) in the seasons 1988/89 (Isaksson and Karlén, 1994) and 1991/92 (Isaksson and others, 1996; this paper) included 11 shallow firn cores along a traverse route starting at Riiser-Larsenisen across Ritscherflya towards Amundsenisen east of the Heimefrontfjella mountains. The latter area was visited again during the Swedish ITASE campaigns in 1993/94, providing accumulation data based on snow pits dated by multi-parameter chemical records (Stenberg and others, 1998). Collaborative Swedish-Norwegian-Dutch activities continued in 1997/98 within EPICA, including snow-pit studies (Stenberg and others, 1999) as well as medium-depth ice-core drillings at Camp Victoria (Karlöf and others, 2000) and a depot of the British Antarctic Survey (BAS) (Hofstede and others, 2004). Within five consecutive seasons from $1995 / 96$ to $1999 / 2000$, EPICA traverse work under the leadership of the German Alfred Wegener Institute (AWI) retrieved more than 30 shallow firn cores and three medium-depth ice cores, with the majority taken on
Amundsenisen, but also close to Neumayer station, in the Heimefrontfjella, and on Ritscherflya (Oerter and others, 1999, 2000; this paper).

In an extensive mass-balance and glacier research project, the Fimbulisen and Jutulstraumen region was traversed by several Norwegian Antarctic Research Expeditions (NARE) in the seasons 1992/93 (Melvold and others, 1998; Melvold, 1999) and 1993/94. They recovered 12 shallow firn cores. In 1996/97 a Norwegian-Swedish-Dutch ground traverse as part of EPICA drilled 15 firn cores along a traverse from Fimbulisen passing Hellehallet and Mühlig-HofmannGebirge and on the plateau along the ice divide leading to the Japanese deep-drilling site at Valkyrjedomen (Dome F). Those records define the eastern boundary of our investigation area (Isaksson and others, 1999; Van den Broeke and others, 1999). NARE fieldworkers in collaboration with Dutch scientists also recovered two medium-depth ice cores on Amundsenisen in 2000/01 (Hofstede and others, 2004) and on Fimbulisen (Kaczmarska and others, 2004). BAS expeditions retrieved two shallow firn cores in 1986/87 (Wolff and Suttie, 1994) and 1987/88 (Mulvaney and Wolff, 1993), the only records available in Coats Land, the southwestern corner of the area of investigation. Ten years later, in 1997/98, BAS in a joint venture with NARE participated in EPICA studies recovering three shallow firn cores (this paper) and one medium-depth ice core on Amundsenisen (Hofstede and others, 2004). The latest available record, at the time of writing, results from AWI firn-core drilling near Heimefrontfjella in 2003/04 (this paper).

\section{SPATIAL AND TEMPORAL VALIDITY OF DATA}

\subsection{Annual local noise and small-scale spatial variability}

Spatial and temporal variations in accumulation are attributed to the combined effects of: (1) air-mass transport pathways; (2) interaction of airflow with topography; and (3) local effects, i.e. sastrugi and redistribution by snowdrift. Post-depositional processes driven by wind reshape the primary precipitation pattern leading to preferential accumulation of material in topographic depressions, in contradiction to the lowered accumulation rates found on crests (e.g. Sommer and others, 2000; Arnold and Rees, 2003; Frezzotti and others, 2005). Complex local wind erosion and redeposition processes occur due to undulations in surface topography at the kilometre scale and more specifically on variations of the downslope surface gradient (e.g. Melvold and others, 1998). King and others (2004) observed large spatial variability in snow accumulation $(20-30 \%$ on a scale of about $1 \mathrm{~km}$ ) even over gentle topography, which was attributed to a highly non-linear relationship between wind speed and snow transport. Stake-line readings and icepenetrating radar (IPR) studies provide continuous accumulation information at high spatial resolution (RichardsonNäslund and others, 1997; Richardson-Näslund 2004; Rotschky and others, 2004; Spikes and others, 2004). For instance, Isaksson and Karlén (1994) found a standard deviation of $70 \%$ of the average annual accumulation using stake measurements at Ritscherflya. Such results raised questions on how representative single-point records are at a regional scale. Their spatial scale of significance has been widely discussed and is a critical point when interpolating over large distances. 


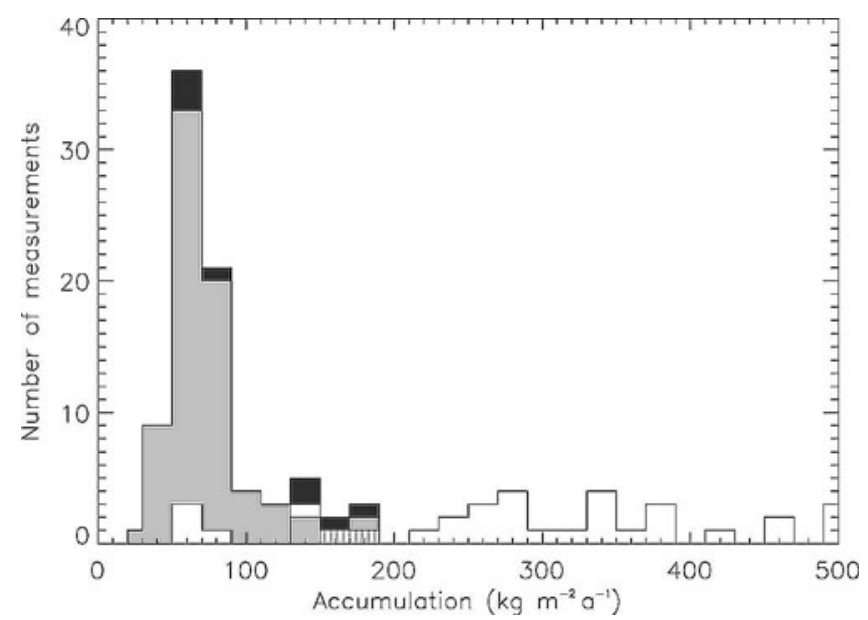

Fig. 2. Frequency distribution of accumulation rates. Grey: records sampled on the plateau (generally below $200 \mathrm{~kg} \mathrm{~m}^{-2} \mathrm{a}^{-1}$ ); white: coastal records; black: total number.

Snow deposition patterns that are highly variable locally are preserved in the form of considerable interannual variability generally detected in firn-core stratigraphy. This phenomenon has been discussed in a large body of literature (e.g. Goodwin, 1991; Frezzotti and others 2004, 2005). Specifications for year-to-year variations range from $30 \%$ on Amundsenisen (Sommer and others, 2000) to as high as $250 \%$ for firn cores drilled on Jutulstraumen (Melvold and others, 1998). High-frequency variability in annual-layer thickness within ice cores is associated in the first place with wind redistribution controlled by micro-relief, rather than with climatically forced precipitation changes (Reijmer and Van den Broeke, 2003; Frezzotti and others, 2005). As a consequence, accumulation time series generally miss a clear correspondence even for nearby firn-core sites (Sommer and others, 2000). Such findings indicate that only multi-year accumulation averages should be used for regional studies. Five to ten years is generally considered sufficient for providing reliable estimates of local snow accumulation (Petit and others, 1982; Morgan, 1985; Mosley-Thompson and others, 1985). We account for this by excluding all records that cover $<5$ years of accumulation, in order to avoid biases in our interpolation map resulting from annual local noise and small-scale spatial variability. When a choice was available between several measurements taken at the same location, we decided on the one with the longer average time interval.

\subsection{Multi-decadal accumulation trends}

Both positive and negative long-term trends in snow accumulation have been reported over the Antarctic ice sheet (e.g. Petit and others, 1982; Morgan and others, 1991; Mosley-Thompson, 1992). Our dataset consists of records that are sampled irregularly in space and time, covering a wide variety of accumulation time periods. Average time intervals range from several years to several hundreds of years, with the majority (78 out of 111$)<50$ years. Sampling was carried out over a time period of roughly 40 years (see Appendix). Therefore, differences in accumulation values might partly originate from a changing accumulation rate over time. This could induce misinterpretations when modelling spatial variations statistically in order to define optimal interpolation criteria for applying geostatistical surface prediction methods, i.e. kriging (see section 6). Whether this dataset is suitable for compiling an accumulation map must therefore be investigated.

All investigators involved in data sampling agree that time series of accumulation rates and stable isotopes do not indicate a drastic change in atmospheric moisture transport in DML over the covered time periods of their studies (e.g. Isaksson and others, 1996; Melvold, 1999; Oerter and others, 1999; Karlöf and others, 2000). At decadal timescales, the records show no clear trend or different magnitude and direction in changes between the single sites. Oerter and others (1999) and Graf and others (2002) observed temporal variations over the last two centuries in central DML that were linked to temperature variations derived from records of stable isotopes. However, for the same region, constant accumulation rates characterized the last 2000 years in three intermediate-depth ice cores (Sommer and others, 2000). Slight increases or decreases in accumulation rates over several decades were found to be small compared with interannual variability. This is in accordance with the findings of Isaksson and others (1996) and Hofstede and others (2004) who combined information from different sites on Amundsenisen. We found a stable plateau climate by comparing cores $M$ and M150 (see Appendix). Both were drilled at $75^{\circ} 00^{\prime} \mathrm{S}, 15^{\circ} 00^{\prime} \mathrm{E}$ and they cover a time period of 31 and 1033 years, respectively. Despite the different average time intervals, similar accumulation values of 43 and $45 \mathrm{~kg} \mathrm{~m}^{-2} \mathrm{a}^{-1}$, respectively, indicate stable accumulation rates for the longest time interval included in this study.

Coastal areas experience stronger climatic fluctuations since they are exposed to the combined effects of changing sea-ice extent and cyclonic activity (Isaksson and Karlén, 1994; Kaczmarska and others, 2004). However, since observed changes (e.g. Isaksson and others, 1996; Melvold, 1999) are generally restricted in time and show alternating signs and no inter-site correlation, a likely explanation is the movement of a borehole site through a complex undulation pattern related to bedrock topography (Melvold and others, 1998; Sommer and others, 2000). Depending on ice-flow velocity and wavelength of surface undulations (in the order of some kilometres) (Richardson-Näslund and others, 1997; Rotschky and others, 2004; Eisen and others, 2005), a coring site requires several decades to travel from a lowaccumulation surface crest to a high-accumulation surface hollow. For this reason an apparent trend may be detected from changes in annual-layer thickness of firn cores, even in stable climatic periods. However, the average accumulation derived from the affected firn core would still be representative for a larger surrounding area. Based on these data, we assume that no major change in accumulation occurred in western DML during the past 1000 years that would significantly corrupt the quality of a spatially interpolated picture of accumulation rates over our area of interest.

\section{EXPLORATORY SPATIAL DATA ANALYSIS}

Nearly all 111 selected accumulation records result from traverse work conducted by different nations as described above. Therefore, data collection did not follow an optimal sampling procedure. The resulting sampling density varies and remains relatively small considering the well-known high spatial variability of snow accumulation, particularly in mountainous areas. In order to define suitable parameters 
Table 1. Statistical distribution of accumulation value in $\mathrm{kg} \mathrm{m}^{-2} \mathrm{a}^{-1}$

\begin{tabular}{lcccc}
\hline & Total & Coast & Plateau & $\begin{array}{c}\text { Plateau } \\
\text { logarithmic } \\
\text { transformation }\end{array}$ \\
\hline Number of records & 111 & 36 & 75 & 75 \\
Mean & 130 & 271 & 62 & 4.04 \\
Median & 64 & 271 & 56 & 4.03 \\
Min. & 19 & 46 & 19 & 2.94 \\
Max. & 491 & 491 & 171 & 5.14 \\
Std dev. & 124.2 & 128.2 & 30.0 & 0.42 \\
Skewness & 1.46 & -0.06 & 1.86 & 0.37 \\
& & & & \\
\hline
\end{tabular}

for a spatial interpolation we first examined the statistical properties of our dataset, i.e. value distribution, spatial variability and global spatial trends.

\subsection{Value distribution}

Accumulation records range from as low as $19 \mathrm{~kg} \mathrm{~m}^{-2} \mathrm{a}^{-1}$ at the south eastern corner of our study area on Amundenisen to a maximum of $491 \mathrm{~kg} \mathrm{~m}^{-2} \mathrm{a}^{-1}$ on Jutulstraumen. By looking at the number of records measured within defined accumulation intervals in steps of $20 \mathrm{~kg} \mathrm{~m}^{-2} \mathrm{a}^{-1}$, we find our dataset is not normally distributed (Fig. 2). A bell-shaped histogram would be required for an optimal interpolation result. Instead, the majority of records are lower than $200 \mathrm{~kg} \mathrm{~m}^{-2} \mathrm{a}^{-1}$, causing the histogram bars to be clearly shifted to the left. The highest number of records (36) fall into the accumulation interval between 45 and $65 \mathrm{~kg} \mathrm{~m}^{-2} \mathrm{a}^{-1}$, while medium and higher values are underrepresented in our dataset. This skewness is also expressed by a large difference between the median $\left(63.5 \mathrm{~kg} \mathrm{~m}^{-2} \mathrm{a}^{-1}\right)$ and the mean value $\left(129.49 \mathrm{~kg} \mathrm{~m}^{-2} \mathrm{a}^{-1}\right)$, which in turn is of the same order as the standard deviation of $124.67 \mathrm{~kg} \mathrm{~m}^{-2} \mathrm{a}^{-1}$. The considerably higher proportion of low data values within the dataset is clearly due to the preferential sampling on the DML plateau area (75 out of 111 records). Data points with values higher than $200 \mathrm{~kg} \mathrm{~m}^{-2} \mathrm{a}^{-1}$ are, without exception, located near the coast and the adjacent lower inland regions north of the nunataks, while nearly all records below this threshold belong to the inland plateau. Already from this frequency distribution two separate accumulation regimes can be distinguished.

By looking at the accumulation values separately for coastal and plateau regions, we find a distribution close to normal for the coast, expressed by similar mean and median values (Table 1). The coastal records account for the high standard deviation in our dataset, with a value of 128.2 compared with only $30.0 \mathrm{~kg} \mathrm{~m}^{-2} \mathrm{a}^{-1}$ for the plateau. The latter is in agreement with the findings of Oerter and others (1999). The higher spread in accumulation values for the coastal data is not surprising, considering the complex geographical nature described earlier. However, the relative standard deviation is similar for both regions. For the subset of records located on the plateau a distribution close to normal can be found by performing a logarithmic transformation of our data values. By this we can adjust the coefficient of skewness, a measure of the symmetry of a distribution, which should be near zero for optimal interpolation results.

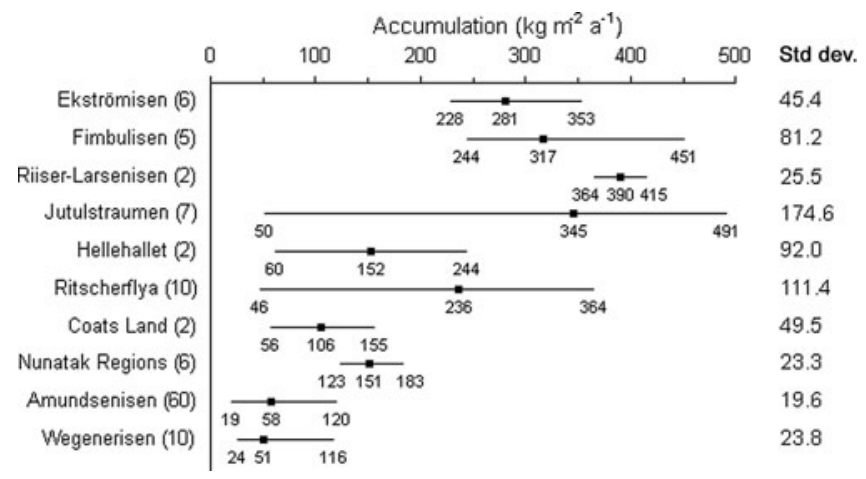

Fig. 3. Minima, mean and maxima of accumulation rates for individual regions. The number of respective records is given in brackets.

For individual regions within the area of investigation we find distinct differences in accumulation mean and spread (Fig. 3). We are aware that the number of records is a critical factor for such comparisons, particularly for the nunatak areas. Amundsenisen and Wegenerisen exhibit smooth topography and remote location with low spread and values generally lower than $120 \mathrm{~kg} \mathrm{~m}^{-2} \mathrm{a}^{-1}$. In contrast, the data are highly variable for coastal regions. The most striking region is Jutulstraumen, which covers the entire range of accumulation values within our dataset. This large spatial variation in accumulation has been attributed to strong erosion and redeposition processes on the ice stream controlled by surface undulations and a complex near-surface wind field (Holmlund and Näslund, 1994). Accumulation extremes also result from increased precipitation between 900 and $1200 \mathrm{~m}$ elevation due to orographic uplift and adiabatic cooling of humid air masses (Melvold and others, 1998).

\subsection{Outliers}

Outliers within a dataset can affect the performance of a surface prediction dramatically by distorting the variogram modelling associated with the kriging procedure later used for the interpolation. They should therefore be identified prior to the interpolation (Burrough, 1986). There are no global outliers within our dataset, i.e. no records are very high or very low relative to all of the values. However, at four locations we find sample points within the normal range of the entire dataset, but exhibiting unusually low values relative to their neighbours. Major accumulation deficits are found for core sites Jut_E $\left(72^{\circ} 13^{\prime} \mathrm{S}, 00^{\circ} 43^{\prime} \mathrm{W}\right)$ and Jut_I $\left(71^{\circ} 31^{\prime} \mathrm{S}, 01^{\circ} 11^{\prime} \mathrm{W}\right)$, both located on Jutulstraumen, which have been linked to strong katabatic wind activity as indicated by wind crusts, sastrugi and nearby blue-ice fields (Melvold and others, 1998). Anomalous low values also characterize core sites B10_11 (72 $\left.30^{\prime} \mathrm{S}, 09^{\circ} 06^{\prime} \mathrm{W}\right)$ and ' $\mathrm{km}$ $270^{\prime}\left(72^{\circ} 56^{\prime} \mathrm{S}, 09^{\circ} 41^{\prime} \mathrm{W}\right)$, situated on Ritscherflya at about $1000 \mathrm{~m}$ a.s.I. From field observations and isotope analysis it was found that these low values are also due to erosion by wind activity and were not caused by lower precipitation rate (Oerter and others, 1999). From stake-line readings (Rotschky and others, 2006) and IPR measurements (Richardson-Näslund and others, 1997) we know that these core sites are situated within a wider zone of very low accumulation rates, which is likely a consequence of strong katabatic winds originating in the Heimefrontfjella range. We can therefore conclude that all the local outliers have been measured correctly and represent real abnormalities, 


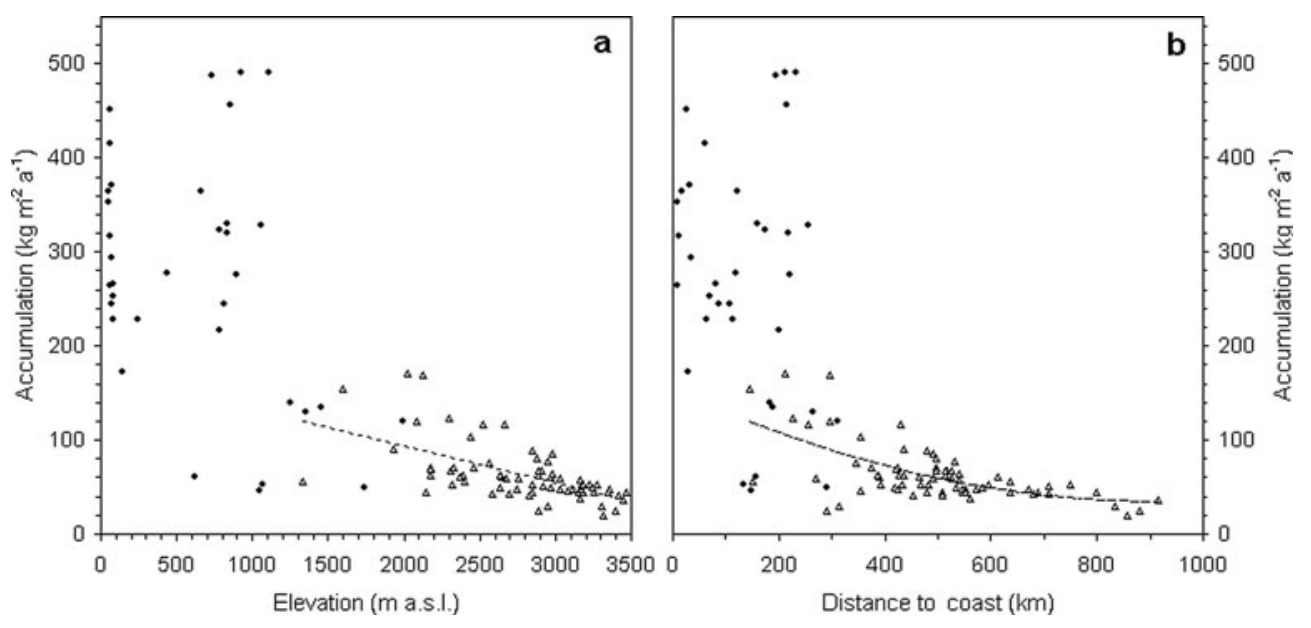

Fig. 4. Global trends. Correlations between accumulation rates and (a) elevation and (b) distance to the coast. Coastal records are shown as black dots; records sampled on plateau regions are shown as triangles.

reflecting the high spatial accumulation variability in complex terrain. We expect that measuring errors are not a major problem for interpolation of the dataset.

\subsection{Global spatial trends}

To identify global spatial trends we examined possible relationships between snow accumulation and distance to the nearest coast, elevation as well as slope gradient and orientation. These variables are often used to explain the general distribution of snow accumulation rates (e.g. Giovinetto and others, 1990; Bernhard and Weibel, 1999). Terrain information was extracted from the RADARSAT-1 Antarctic Mapping Project (RAMP) digital elevation model (H. Liu and others, http://nsidc.org/data/nsdic-0082.html). The ice front was taken from the Antarctic Digital Database (ADD) version 4, provided by the Scientific Committee on Antarctic Research (SCAR). Using the entire dataset, we did not find a correlation between accumulation rates and the chosen parameters. For instance, both the lowest $\left(46 \mathrm{~kg} \mathrm{~m}^{-2} \mathrm{a}^{-1}\right)$ and highest $\left(491 \mathrm{~kg} \mathrm{~m}^{-2} \mathrm{a}^{-1}\right)$ coastal values are found within the elevation interval 900-1100 m a.s.l. at a distance of 200-250 km from the coast. Even on the flat ice shelves, accumulation ranges from 228 to $451 \mathrm{~kg} \mathrm{~m}^{-2} \mathrm{a}^{-1}$. Clear cross-correlations between slope gradient and accumulation reported by Melvold and others (1998) or King and others (2004) apply only for limited areas.

Excluding all coastal records from the analysis yields an expected negative cross-correlation between accumulation and elevation as well as distance to the nearest coast each with $R=-0.6$. As with Giovinetto and others (1990), we can describe those relations using first- and second-order regression functions (Fig. 4). Concerning continentality, the correlation improves when moving gradually away from the coast (Table 2). The best correlation of $R=-0.8$ was found for the distance interval $700-1000 \mathrm{~km}$ from the coast, indicating that other reasons for spatial accumulation variations (e.g. surface undulations) become less important inland.

\section{SURFACE PREDICTION}

\subsection{Semivariogram modelling}

The process of variogram modelling, i.e. variography, is an instrument for characterizing the spatial variability of a dataset. It gives useful information for selecting optimal interpolation parameters (e.g. the mathematical model to be used for computing efficient interpolation weights, the size and shape of the search window, as well as the number of neighbouring measurement sites to be included in the prediction of unsampled sites). In order to estimate accumulation rates for the western DML region, we used kriging as the geostatistical interpolation method. Fundamental to kriging is the assumption that a relationship exists between the location of sites and the measured values, which can be modelled statistically. In theory the difference in values should be the same between any two points that are the same distance and direction apart. Naturally, dissimilarities between records increase with distance since nearby samples tend to be more alike than those farther apart. The degree of spatial autocorrelation is estimated from the data based on a scatter plot of half of the squared difference between pairs of sample values against their spatial separation, $h$, called the semivariogram cloud. An average of dissimilarities, $y^{*}(h)$, is calculated for all sample pairs falling into a certain distance bin of defined size, i.e. the lag size. The theory concerning kriging is discussed in more detail by Burrough (1986) and Wackernagel (1998).

\subsection{Interpolation settings}

Following the exploratory spatial data analysis, the dataset was separated into coastal and inland sites in order to define a set of domain-specific interpolation criteria. Different statistical properties suggest using two local models, rather than a single global model, for the interpolation, even though for the coastal domain the number of records becomes a critical factor for achieving a stable semi-variogram. The Heimefrontfjella, Kirwanveggen and Mühlig-HofmannGebirge mark the borderline between the data subsets. To improve the western boundary conditions, where data are missing over large distances, we used data from Coats Land for both domains.

The selection of a proper set of interpolation parameters is highly subjective. However, we found that the resulting patterns remained quite stable for reasonable values of tested interpolation parameters. Even the specific variogram model type, used for computing interpolation weights, seems to be of minor influence. Over the smooth plateau region, where accumulation variability is relatively small, 
Table 2. Global trends: correlation coefficients $(R)$ between accumulation rates and elevation as well as distance to the coast

\begin{tabular}{lccccc}
\hline $\begin{array}{l}\text { Distance } \\
\text { interval } \\
\mathrm{km}\end{array}$ & $\begin{array}{c}\text { Number of } \\
\text { records }\end{array}$ & $R$ & $\begin{array}{c}\text { Elevation } \\
\text { interval } \\
\text { ma.s.l. }\end{array}$ & $\begin{array}{c}\text { Number of } \\
\text { records }\end{array}$ & $R$ \\
\hline $150-1000$ & 75 & -0.60 & $1300-3500$ & 75 & -0.60 \\
$400-1000$ & 58 & -0.61 & $2000-3500$ & 72 & -0.57 \\
$500-1000$ & 37 & -0.68 & $2500-3500$ & 55 & -0.52 \\
$600-1000$ & 17 & -0.80 & $3000-3500$ & 26 & -0.51 \\
\hline
\end{tabular}

we selected a spherical model type which shows a progressive decrease of spatial autocorrelation until some distance, beyond which the autocorrelation becomes zero. For the coastal domain, a circular model type with a steeper curve near the origin, giving more weight to the closest neighbours for each prediction, is more appropriate. Variations in lag size and number did not significantly affect the output surface. A lag size of $20 \mathrm{~km}$ was chosen for both domains in order to get representative averages for semivariogram bins.

Concerning the number of measured values to be used in a prediction, stable results are computed including at least two to five neighbours in all four directions. Any further increase in the number of neighbours has no impact on the resulting pattern because of the decreasing influence of remote points. The specific shape of the neighbourhood determines where to look for data points. A clear indication for selecting optimal search radii is given by the range of the semivariogram cloud defining the distance to which data are statistically correlated (Burrough, 1986). Higher autocorrelation in one direction than in another might result from global trends and/or anisotropy. Our earlier spatial data analysis showed a first-order trend on the plateau running from northwest to southeast towards increasing elevation and distance to coast, which was removed before variogram modelling and added back before predictions were made. From variography we still find anisotropic autocorrelation for this region, i.e. values in northeast-southwest direction change more slowly than perpendicular to this. Such a phenomenon can be explained from topography and resultant predominant wind direction, as modelled for example by Van Lipzig and others (2004). Therefore, we assume that these directional differences are not a measurement artefact resulting from the preferential alignment of records along traverse lines which could lead to insufficient sampling density for robust estimates in all directions. Consequently, we accounted for this anisotropic spatial autocorrelation by applying varying search radii as described below.

In general, we found a single plateau record to be representative for a larger area than coastal records. This is in agreement with other findings (Stenberg and others, 1999). The spatial autocorrelations suggest that the search radii should be $200-250 \mathrm{~km}$ from northeast to southwest and $100-150 \mathrm{~km}$ perpendicular to this direction. For the coastal domain, where major variation occurs over shorter distances, the search radius was kept as small as possible (80$125 \mathrm{~km}$ in any direction). Little variations in search radii led to changes in the predicted surface, particularly in the coastal area. Since the most efficient search radius remains a
Table 3. Interpolation settings

\begin{tabular}{|c|c|c|}
\hline Setting & Coastal domain & $\begin{array}{l}\text { Plateau domain } \\
\text { (interior region) }\end{array}$ \\
\hline Geostatistical method & Ordinary kriging & Universal kriging \\
\hline Transformation & None & $\log$ \\
\hline Trend & None & Linear \\
\hline Model type & Spherical & Circular \\
\hline Lag size (m) & \multicolumn{2}{|c|}{20000} \\
\hline Lag No. & \multicolumn{2}{|c|}{15} \\
\hline Neighbours & \multicolumn{2}{|c|}{5 , at least 2 per search quarter } \\
\hline Search window & & \\
\hline Anisotropy & No & Yes (northwest-southeast) \\
\hline Axis angle & $45^{\circ}$ & $65^{\circ}$ \\
\hline Major axis $(\mathrm{km})$ & $80-125$ & $205-250$ \\
\hline Minor axis (km) & $80-125$ & $105-150$ \\
\hline
\end{tabular}

subject of speculation, a good solution is to produce an average composite of ten realizations, each time adjusting the search window by slightly enlarging its two axes (i.e. the search radii) in $5 \mathrm{~km}$ steps. The differences between these predictions are used as a measure of uncertainty in the predicted surface.

Having computed the experimental variograms and fitted model parameters, our accumulation records were interpolated using ordinary kriging for the coast and universal kriging for the plateau domain. The latter should be applied only if an apparent spatial trend in the data can be explained from a priori knowledge (Burrough, 1986). Using a logarithmic transformation makes the data more normally distributed in case of the plateau domain. Here, the interpolation was carried out using the logarithmically transformed data which were then transformed back. Our interpolation settings are summarized in Table 3.

\section{RESULTS AND DISCUSSION}

\subsection{Surface prediction}

The resulting accumulation distribution is mapped in Figure 5. Clearly, predicting a surface from sparse point data gives only a smoothed picture of the underlying reality. Details of spatial accumulation variability cannot be reproduced and the resulting pattern is highly dependent on the random distribution of sample points. For the coastal area, high accumulation alternates with accumulation lows reflecting a spatial variability in precipitation and snow transport that is topographically forced. Isolated circular patterns around single records result from values that deviate significantly from their surrounding neighbours. On the plateau, a clear trend of decreasing accumulation with increasing distance to coast and elevation from northwest to southeast (as described above) is reproduced. Values range from $150 \mathrm{~kg} \mathrm{~m}^{-2} \mathrm{a}^{-1}$ just south of the mountain ridges down to as little as $25 \mathrm{~kg} \mathrm{~m}^{-2} \mathrm{a}^{-1}$ near the southeastern corner of our study area. Tongue-shaped patterns of higher accumulation advance from coastal regions further inland, where nunatak barriers are absent over larger distances (e.g. south of Jutulstraumen and Coats Land). Some problems are visible near Mühlig-Hofmann-Gebirge where predicted values at the northern margin of the plateau domain increase rapidly over short distances. In this area, computed accumulation 


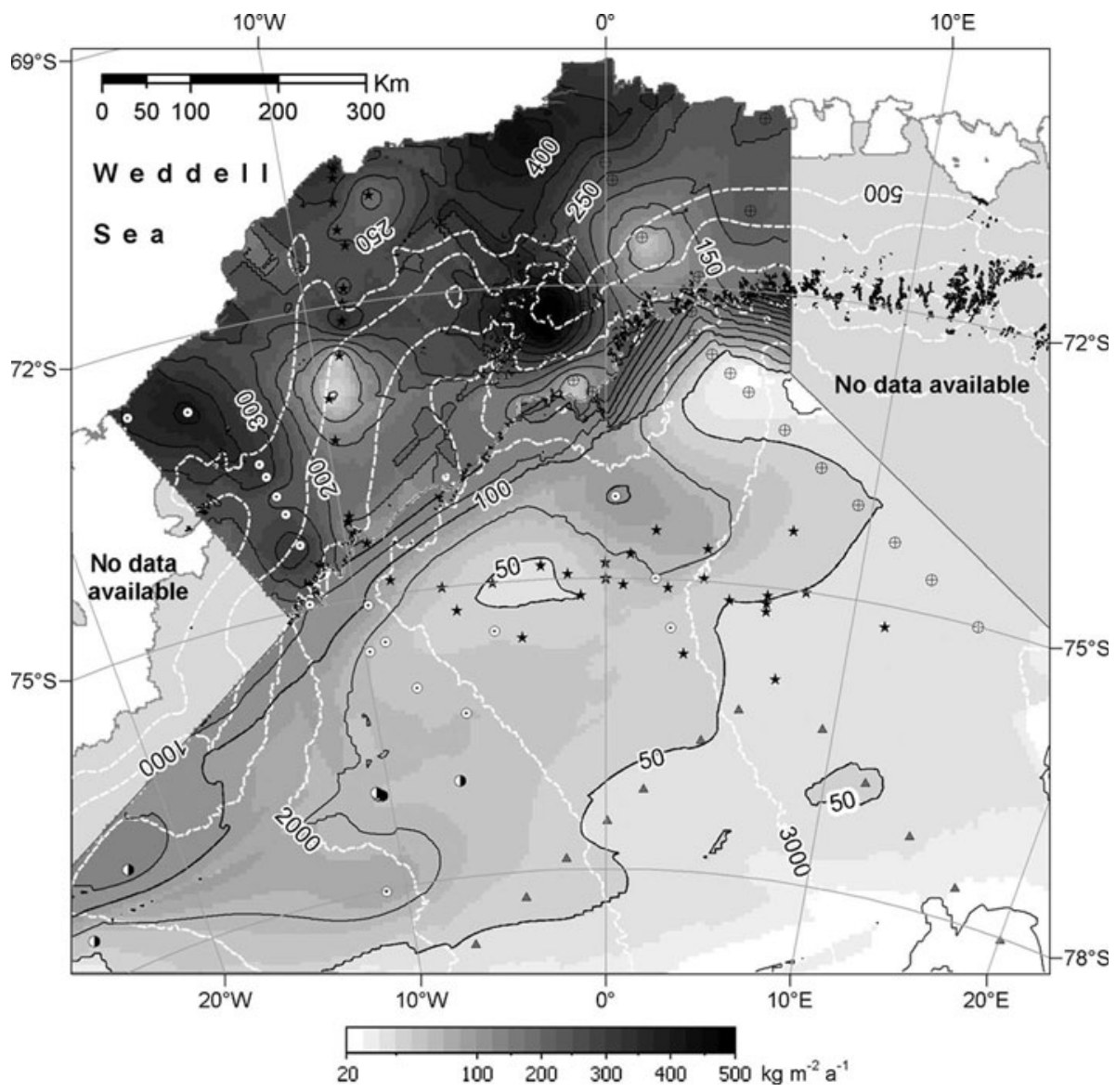

Fig. 5. Contoured accumulation pattern for western DML (data are available from the PANGAEA ${ }^{\mathbb{R}}$ website http://doi.pangaea.de/10.1594/ PANGAEA.472297). A greyscale as well as contours at 50 (coastal domain) and $25 \mathrm{~kg} \mathrm{~m}^{-2} \mathrm{a}^{-1}$ (plateau domain) are used to indicate the broad spatial variability in snow accumulation across the predicted area. Elevation contours in $500 \mathrm{~m}$ intervals are shown as dashed white curves. The borderline between coastal and plateau domain follows the mountain chains and is shown as solid grey line.

rates are unreliable. Further interpolation difficulties occur where in situ data are missing over large distances between traverse lines running inland from the coast. The resulting striped patterns are clearly an artefact of the interpolator and not representative of the true accumulation.

Due to interpolation uncertainties as a result of the sparse and uneven data-sampling scheme, estimating the total surface mass balance in western DML is difficult. In spite of the larger area, the total accumulation on the plateau $\left(58 \times 10^{4} \mathrm{~km}^{2}\right)$ sums up to only $38 \mathrm{Gta}^{-1}$ vs $62 \mathrm{Gta}^{-1}$ for the coastal region with a spatial extent of $24 \times 10^{4} \mathrm{~km}^{2}$. Discrepancies in total accumulation between our ten slightly varied realizations are marginal (generally $<1 \%$ ). In Table 4 we compare our results with previous accumulation

Table 4. Total accumulation in western DML: comparison between this study and earlier published results

\begin{tabular}{lcccc}
\hline & $\begin{array}{c}\text { Coastal } \\
\text { domain } \\
\mathrm{Gt} \mathrm{a}^{-1}\end{array}$ & $\begin{array}{c}\text { Plateau } \\
\text { domain }\end{array}$ & Total & Difference \\
& & & $\mathrm{Gt} \mathrm{a}^{-1}$ & $\%$ \\
\hline This paper & 62.0 & 37.7 & 99.7 & - \\
Vaughan and others (1999) & 63.4 & 54.5 & 117.9 & +18.3 \\
Huybrechts and others (2000) & 74.5 & 41.3 & 115.8 & +16.2 \\
Arthern and others (2006) & 49.1 & 37.4 & 86.5 & -13.3 \\
\hline
\end{tabular}

compilations by Vaughan and others (1999) and Arthern and others (2006), who both guided the interpolation using background fields of satellite microwave observations, as well as by Huybrechts and others (2000), who applied a spline interpolation to nearly the same input data as in the present study. While the results of Vaughan and others (1999) and Huybrechts and others (2000) are 18\% and 16\% larger, respectively, the recently published findings by Arthern and others (2006) yield about 13\% less accumulation for the western DML area than this study. These differences result from significantly higher estimates for the plateau in the case of Vaughan and others (1999) and for the coastal area in the case of Huybrechts and others (2000). Conversely, Arthern and others (2006) yield similar estimates for the plateau; however, their coastal estimates are significantly lower than ours. Generally the same input data have been used in all of the studies, which suggests that differences occur due to approaches to interpolation. In general, spline interpolation may produce local artefacts of excessively high or low values if input values change dramatically over short distances. Therefore, the results of Huybrechts and others (2000) are unreliable for the DML coastal area. The main reason for the disagreements is the absence of a barrier between the coastal and plateau accumulation regimes in the earlier studies, which results in an overestimation of the area of validity of highaccumulation coastal records in the case of Vaughan and others (1999) and of low-accumulation plateau records in 


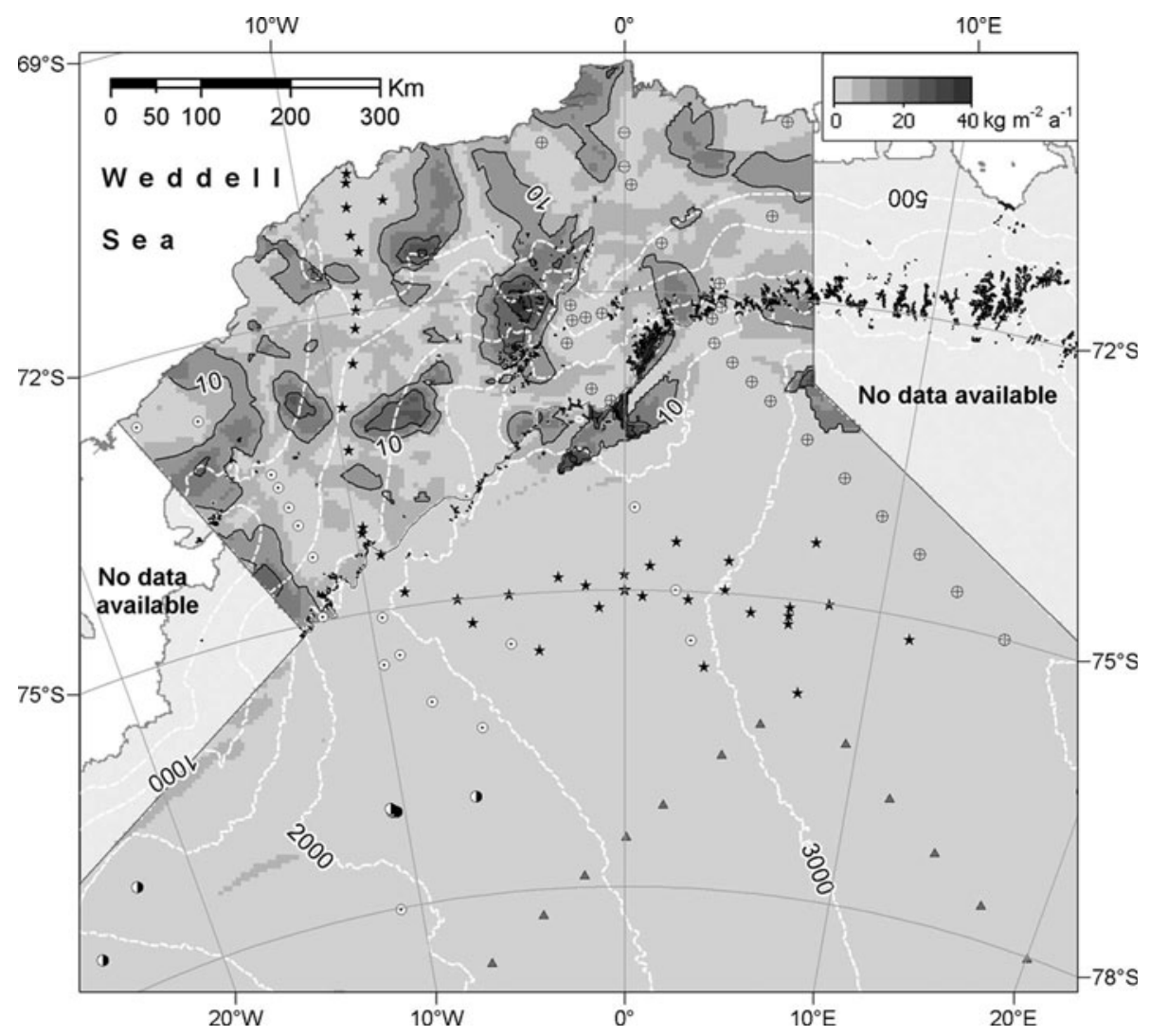

Fig. 6. Map of standard deviation between ten predictions with stepwise increase of search radii (data available from the PANGEA website http://doi.pangaea.de/10.1594/PANGAEA.472298). A greyscale and contours at $10 \mathrm{~kg} \mathrm{~m}^{-2} \mathrm{a}^{-1}$ (black lines) indicate the interpolation inaccuracy. Elevation contours in $500 \mathrm{~m}$ intervals are shown as dashed white curves. The borderline between coastal and plateau domain follows the mountain chains and is shown as solid grey line.

the case of Arthern and others (2006). Like those of Arthern and others (2006), our results indicate that snow accumulation in western DML is probably smaller than previously assumed.

\subsection{Interpolation accuracy}

In general, accuracies vary across a predicted area with datasampling density. To evaluate the uncertainty of the interpolated surface, an error estimate is required. In the absence of an extra set of independent observations randomly distributed across the predicted area, we cannot quantify the accuracy directly. From the relatively small number of available data, a subset for validation purposes could not be created before interpolation. Each point in the dataset is essential for the variogram modelling and original prediction.

Some measure of certainty is provided as a by-product of the kriging procedure, known as the kriging variance. In the literature, this quantity has been criticized as being ineffective and a poor substitute for a true error (e.g. Journel, 1986; Chainey and Stuart, 1998). The kriging variance, depending only on the geometrical arrangement of the sample data points, simply states that accuracy decreases with growing distance from input data.

As a measure of confidence we instead used the differences between the ten interpolation realizations, each with slight adjustments in the applied search window, as described above. The lower the standard deviation of the different predictions, the more accurate the interpolation is likely to be in terms of self-consistency of the model applied to the data. The standard deviations across the predicted area are mapped in Figure 6, expressing a clear difference between coastal and plateau domains. On the plateau, data density seems sufficient for achieving stable interpolation results, with the exception of the Jutulstraumen inlet area. In contrast, for coastal regions, exhibiting a much larger spatial accumulation variation, major interpolation uncertainties occur for unsampled locations between measurement sites. Clearly, small adjustments in the shape of the search window impact mostly where single values deviate greatly from their surrounding neighbours (local singularities, as described above). This result leads back to the question of how representative single-point records are for their wider surrounding. In order to catch the full range of accumulation variability occurring due to the complex coastal terrain and wind-field conditions, further data acquisition should be carried out in directions other than from north to south. Regional climate modelling may also help in this respect (Van den Broeke and others, 2006).

\section{SUMMARY AND CONCLUSIONS}

A set of 111 accumulation measurements from western DML is compiled and presented. Most data result from fieldwork carried out over the last 15 years in the framework of EPICA and ITASE. Older records from the literature are used to supplement the data. In spite of a large variety of covered accumulation periods, ranging between 5 and 1000 years, we find the datasets temporally representative, as no significant trend in accumulation history over the last few centuries has been reported from ice-core records of this 
region. Uneven data distribution resulting from preferential alignment of measurement sites along traverse lines, which lead mostly inland from the coast, is a more critical factor for judging the spatial accumulation variability. Nevertheless, an interpolated map of mean annual snow-accumulation rate could be derived that is in accordance with presumptions made from known overall spatial trends and topographically forced changes in accumulation. The interpolation was carried out using the geostatistical interpolation method of kriging, based on two local models and domain-specific interpolation settings for coastal and inland sites. Our results suggest that the total accumulation rate for the predicted area is about $16-18 \%$ smaller than published in earlier studies. For a quantitative evaluation of the uncertainty in predicted accumulation rates, we calculated the standard deviation of ten interpolation estimations, each with a slight stepwise increase in search radii. A map of the standard deviation thus obtained could help in locating future sampling sites to further minimize interpolation uncertainties. The existing sampling network should be improved with respect to surface topography and associated surface wind-field patterns which in combination have the potential to change accumulation conditions dramatically over short distances, especially in the complex terrain of the coastal regions. These results are of interest for the interpretation of climate records from the study area, as well as for ongoing surface mass-balance modelling aimed at resolving the fine-scale accumulation pattern across western DML.

\section{ACKNOWLEDGEMENTS}

This work is a contribution to the European Project for Ice Coring in Antarctica (EPICA), a joint European Science Foundation (ESF))/European Commission (EC) scientific programme, funded by the European Union and by national contributions from Belgium, Denmark, France, Germany, Italy, The Netherlands, Norway, Sweden, Switzerland and the United Kingdom. The main logistical suppoert was provided by Institut Polaire Français-Emile Victor (IPEV) and Programma Nazionale di Richerche in Antartide (PNRA) (at Dome C) and AWI (at DML). This is EPICA publication No. 175. We thank the scientific editor R. Bindschadler and two anonymous reviewers for valuable comments on the manuscript.

\section{REFERENCES}

Arnold, N.S. and W.G. Rees. 2003. Self-similarity in glacier surface characteristics. J. Glaciol., 49(167), 547-554.

Bernhard, L. and R. Weibel. 1999. Modelling snowmelt using a digital terrain model and GIS-based techniques. In Dikau, R. and H. Saurer, eds. GIS for earth surface systems analysis and modelling of the natural environment. Stuttgart, Gebr. Borntraeger.

Budd, W.F. and D.B. Carter. 1971. An analysis of the relation between the surface and bedrock profiles of ice caps. J. Glaciol., 10(59), 197-209.

Burrough, P.A. 1986. Principles of geographical information systems for land resources assessment. Oxford, Clarendon Press.
Chainey, S. and N. Stuart. 1998. Stochastic simulation: an alternative interpolation technique for digital geographic information. In Carver, S., ed. Innovations in GIS 5: selected papers from the Fifth National Conference on GIS Research UK (GISRUK). London, Taylor \& Francis, 3-24.

Eisen, O., W. Rack, U. Nixdorf and F. Wilhelms. 2005. Characteristics of accumulation around the EPICA deep-drilling site in Dronning Maud Land, Antarctica. Ann. Glaciol., 41, 41-56.

Frezzotti, M. and 12 others. 2004. New estimations of precipitation and surface sublimation in East Antarctica from snow accumulation measurements. Climate Dyn., 23(7-8), 803-813.

Frezzotti, M. and 13 others. 2005. Spatial and temporal variability of snow accumulation in East Antarctica from traverse data. J. Glaciol., 51(172), 113-124.

Giovinetto, M.B. and C.R. Bentley. 1985. Surface balance in ice drainage systems of Antarctica. Antarct. J. US, 20(4), 6-13.

Giovinetto, M.B. and H.J. Zwally. 2000. Spatial distribution of net surface accumulation on the Antarctic ice sheet. Ann. Glaciol., 31, 171-178.

Giovinetto, M.B., N.M. Waters and C.R. Bentley. 1990. Dependence of Antarctic surface mass balance on temperature, elevation, and distance to open ocean. J. Geophys. Res., 95(D4), 3517-3531.

Goodwin, I.D. 1991. Snow-accumulation variability from seasonal surface observations and firn-core stratigraphy, eastern Wilkes Land, Antarctica. J. Glaciol., 37(127), 383-387.

Gow, A.J. 1965. On the accumulation and seasonal stratification of snow at the South Pole. J. Glaciol., 5(40), 467-477.

Gow, A.J. and R. Rowland. 1965. On the relationship of snow accumulation to surface topography at "Byrd Station", Antarctica. J. Glaciol., 5(42), 843-847.

Graf, W. and 6 others. 2002. Stable-isotope records from Dronning Maud Land, Antarctica. Ann. Glaciol., 35, 195-201.

Hofstede, C.M. and 10 others. 2004. Firn accumulation records for the past 1000 years on the basis of dielectric profiling of six cores from Dronning Maud Land, Antarctica. J. Glaciol., 50(169), 279-291.

Holmlund, P. and J.O. Näslund. 1994. The glacially sculptured landscape in Dronning Maud Land, Antarctica, formed by wetbased mountain glaciation and not by the present ice sheet. Boreas, 23(2), 139-148.

Huybrechts, P., D. Steinhage, F. Wilhelms and J. Bamber. 2000. Balance velocities and measured properties of the Antarctic ice sheet from a new compilation of gridded data for modelling. Ann. Glaciol., 30, 52-60.

Isaksson, E. and W. Karlén. 1994. Spatial and temporal patterns in snow accumulation, western Dronning Maud Land, Antarctica. J. Glaciol., 40(135), 399-409.

Isaksson, E., W. Karlén, N. Gundestrup, P. Mayewski, S. Whitlow and M. Twickler. 1996. A century of accumulation and temperature changes in Dronning Maud Land, Antarctica. J. Geophys. Res., 101(D3), 7085-7094.

Isaksson, E., M.R. van den Broeke, J.G. Winther, L. Karlöf, J.F. Pinglot and N. Gundestrup. 1999. Accumulation and proxy-temperature variability in Dronning Maud Land, Antarctica, determined from shallow firn cores. Ann. Glaciol., 29, 17-22.

Journel, A.G. 1986. Geostatistics: models and tools for the earth sciences. J. Int. Assoc. Math. Geol., 18(1), 119-140.

Kaczmarska, M. and 10 others. 2004. Accumulation variability derived from an ice core from coastal Dronning Maud Land, Antarctica. Ann. Glaciol., 39, 339-345. 
Karlöf, L. and 13 others. 2000. A 1500 year record of accumulation at Amundsenisen, western Dronning Maud Land, Antarctica, derived from electrical and radioactive measurements on a 120 m ice core. J. Geophys. Res., 105(D10), 12,471-12,483.

Karlöf, L. and 11 others. 2005. Accumulation variability over a small area in east Dronning Maud Land, Antarctica, as determined from shallow firn cores and snow pits: some implications for ice-core records. J. Glaciol., 51(174), 343-352.

King, J.C., P.S. Anderson, D.G. Vaughan, G.W. Mann, S.D. Mobbs and S.B. Vosper. 2004. Wind-borne redistribution of snow across an Antarctic ice rise. J. Geophys. Res., 109(D11), D11104. (10.1029/2003JD004361.)

Lunde, T. 1961. On the snow accumulation in Dronning Maud Land. Nor. Polarinst. Skr., 123.

Melvold, K. 1999. Impact of recent climate on glacier mass balance: studies on Kongsvegen, Svalbard and Jutulstraumen, Antarctica. (DSc thesis, University of Oslo.)

Melvold, K., J.O. Hagen, J.F. Pinglot and N. Gundestrup. 1998. Large spatial variation in accumulation rate in Jutulstraumen ice stream, Dronning Maud Land, Antarctica. Ann. Glaciol., 27, 231-238.

Morgan, V.I. 1985. An oxygen isotope-climate record from the Law Dome, Antarctica. Climatic Change, 7(4), 415-426.

Morgan, V.I., I.D. Goodwin, D.M. Etheridge and C.W. Wookey. 1991. Evidence from Antarctic ice cores for recent increases in snow accumulation. Nature, 354(6348), 58-60.

Mosley-Thompson, E. 1992. Paleoenvironmental conditions in Antarctica since A.D. 1500: ice core evidence. In Bradley, R.S. and P.D. Jones, eds. Climate since A.D. 1500. London and New York, Routledge, 572-591.

Mosley-Thompson, E., P.D. Kruss, L.G. Thompson, M. Pourchet and P. Grootes. 1985. Snow stratigraphic record at South Pole: potential for paleoclimatic reconstruction. Ann. Glaciol., 7, 26-33.

Mulvaney, R. and E.W. Wolff. 1993. Evidence for winter/spring denitrification of the stratosphere in the nitrate record of Antarctic firn cores. J. Geophys. Res., 98(D3), 5213-5220.

Noone, D., J. Turner and R. Mulvaney. 1999. Atmospheric signals and characteristics of accumulation in Dronning Maud Land, Antarctica. J. Geophys. Res., 104(D16), 19,191-19,211.

Oerter, H., W. Graf, F. Wilhelms, A. Minikin and H. Miller. 1999. Accumulation studies on Amundsenisen, Dronning Maud Land, by means of tritium, dielectric profiling and stable-isotope measurements: first results from the 1995-96 and 1996-97 field seasons. Ann. Glaciol., 29, 1-9.

Oerter, H. and 6 others. 2000. Accumulation rates in Dronning Maud Land, Antarctica, as revealed by dielectric-profiling measurements of shallow firn cores. Ann. Glaciol., 30, 27-34.

Peel, D. 1992. Ice core evidence from the Antarctic Peninsula. In Bradley, R.S. and P.D. Jones, eds. Climate since A.D. 1500. London and New York, Routledge.

Petit, J.R., J. Jouzel, M. Pourchet and L. Merlivat. 1982. A detailed study of snow accumulation and stable isotope content in Dome C (Antarctica). J. Geophys. Res., 87(C6), 4301-4308.

Picciotto, E., G. Crozaz and W. De Breuck. 1971. Accumulation on the South Pole-Queen Maud Land traverse, 1964-1968. In Crary, A.P., ed. Antarctic snow and ice studies II. Washington, DC, American Geophysical Union, 257-315. (Antarctic Research Series 16.)

Reijmer, C.H. and M.R. van den Broeke. 2003. Temporal and spatial variability of the surface mass balance in Dronning Maud
Land, Antarctica, as derived from automatic weather stations. J. Glaciol., 49(167), 512-520.

Richardson, C. and P. Holmlund. 1999. Spatial variability at shallow snow-layer depths in central Dronning Maud Land, East Antarctica. Ann. Glaciol., 29, 10-16.

Richardson-Näslund, C. 2004. Spatial characteristics of snow accumulation in Dronning Maud Land, Antarctica. Global Planet. Change, 42(1-4), 31-43.

Richardson-Näslund, C., E. Aarholt, S.E. Hamran, P. Holmlund and E. Isaksson. 1997. Spatial distribution of snow in western Dronning Maud Land, East Antarctica, mapped by a groundbased snow radar. J. Geophys. Res., 102(B9), 20,343-20,353.

Rotschky, G., O. Eisen, F. Wilhelms, U. Nixdorf and H. Oerter. 2004. Spatial distribution of surface mass balance on Amundsenisen plateau, Antarctica, derived from ice-penetrating radar studies. Ann. Glaciol., 39, 265-270.

Rotschky, G., W. Rack, W. Dierking and H. Oerter. 2006. Retrieving snowpack properties and accumulation estimates from a combination of SAR and scatterometer measurements. IEEE Trans. Geosci. Remote Sens., 44(4), 943-956.

Schlosser, E., H. Oerter and W. Graf. 1999. Surface mass balance investigations on Ekströmisen, Antarctica, 1980-1996. Ber. Polarforsch/Rep. Pol. Res., 313.

Sommer, S. and 9 others. 2000. Glacio-chemical study spanning the past $2 \mathrm{kyr}$ on three ice cores from Dronning Maud Land, Antarctica. 1. Annually resolved accumulation rates. J. Geophys. Res., 105(D24), 29,411-29,421.

Spikes, V.B., G.S. Hamilton, S.A. Arcone, S. Kaspari and P. Mayewski. 2004. Variability in accumulation rates from GPR profiling on the West Antarctic plateau. Ann. Glaciol., 39, 238-244.

Stenberg, M. and 7 others. 1998. Spatial variability of snow chemistry in western Dronning Maud Land, Antarctica. Ann. Glaciol., 27, 378-384.

Stenberg, M., M. Hansson, P. Holmlund and L. Karlöf. 1999. Variability in snow layering and snow chemistry in the vicinity of two drill sites in western Dronning Maud Land, Antarctica. Ann. Glaciol., 29, 33-37.

Van de Berg, W.J., M.R. van den Broeke, C.H. Reijmer and E. van Meijgaard. 2006. Reassessment of the Antarctic surface mass balance using calibrated output of a regional atmospheric climate model. J. Geophys. Res., 111(D11), D11104. (10.1029/ 2005JD006495.)

Van den Broeke, M.R. and 6 others. 1999. Climate variables along a traverse line in Dronning Maud Land, East Antarctica. J. Glaciol., 45(150), 295-302.

Van den Broeke, M., W.J. van de Berg and E. van Meijgaard. 2006. Snowfall in coastal West Antarctica much greater than previously assumed. Geophys. Res. Lett., 33(2), L02505. (10.1029/2005GL025239.)

Van Lipzig, N.P.M., J. Turner, S.R. Colwell and M.R. van den Broeke. 2004. Short communication: the near-surface wind field over the Antarctic continent. Int. J. Climatol., 24(15), 1973-1982.

Vaughan, D.G., J.L. Bamber, M.B. Giovinetto, J. Russell and A.P.R. Cooper. 1999. Reassessment of net surface mass balance in Antarctica. J. Climate, 12(4), 933-946.

Wackernagel, H. 1998. Multivariate geostatistics: an introduction with applications. Third edition. Berlin, etc., Springer-Verlag.

Wolff, E.W. and E.D. Suttie. 1994. Antarctic snow record of Southern Hemisphere lead pollution. Geophys. Res. Lett., 21(9), 781-784. 


\section{APPENDIX}

Table 5. List of firn- and ice-core $(C)$ and snow-pit (P) measurements sampled over the area of interest (also available from the PANGAEA ${ }^{\circledR}$ website http://doi.pangaea.de/10.1594/pangaea.407654). Records included (i) in the interpolation are marked with a ' $y$ ' in the first row

\begin{tabular}{|c|c|c|c|c|c|c|c|c|}
\hline Site name & $\begin{array}{l}\text { Institution / } \\
\text { campaign }\end{array}$ & $\begin{array}{l}\text { Year } \\
\text { drilled }\end{array}$ & Latitude & Longitude & Period & Accum. & Dating method & Source \\
\hline & & & & & & $\mathrm{kg} \mathrm{m}^{-2} \mathrm{a}^{-1}$ & & \\
\hline
\end{tabular}

\begin{tabular}{|c|c|c|c|c|c|c|c|c|c|c|}
\hline$y$ & SPQML_01 & $P$ & SPQMLT 03 & $1967 / 68$ & $79^{\circ} 08^{\prime} \mathrm{S}$ & $36^{\circ} 43^{\prime} \mathrm{E}$ & $1955-68$ & 35 & Total $\beta$ & Picciotto and others (1971) \\
\hline & SPQML_02 & $\mathrm{P}$ & SPQMLT 03 & $1967 / 68$ & $78^{\circ} 51^{\prime} \mathrm{S}$ & $33^{\circ} 14^{\prime} \mathrm{E}$ & 1955-68 & 37 & Total $\beta$ & Picciotto and others (1971) \\
\hline y & SPQML_03 & $\mathrm{P}$ & SPQMLT 03 & $1967 / 68$ & $78^{\circ} 43^{\prime} \mathrm{S}$ & $29^{\circ} 43^{\prime} \mathrm{E}$ & 1955-68 & 35 & Total $\beta$ & Picciotto and others (1971) \\
\hline y & SPQML_04 & $\mathrm{P}$ & SPQMLT 03 & $1967 / 68$ & $78^{\circ} 35^{\prime} \mathrm{S}$ & $27^{\circ} 05^{\prime} \mathrm{E}$ & 1955-68 & 36 & Total $\beta$ & Picciotto and others (1971) \\
\hline y & SPQML_05 & $\mathrm{P}$ & SPQMLT 03 & $1967 / 68$ & $78^{\circ} 19^{\prime} \mathrm{S}$ & $23^{\circ} 22^{\prime} \mathrm{E}$ & $1955-68$ & 25 & Total $\beta$ & Picciotto and others (1971) \\
\hline & SPQML_06 & $\mathrm{P}$ & SPQMLT 03 & $1967 / 68$ & $78^{\circ} 01^{\prime} \mathrm{S}$ & $20^{\circ} 05^{\prime} \mathrm{E}$ & 1955-68 & 19 & Total $\beta$ & Picciotto and others (1971) \\
\hline & SPQML_07 & $\mathrm{P}$ & SPQMLT 03 & $1967 / 68$ & $77^{\circ} 39^{\prime} \mathrm{S}$ & $17^{\circ} 10^{\prime} \mathrm{E}$ & 1955-68 & 29 & Total $\beta$ & Picciotto and others (1971) \\
\hline & SPQML_08 & $\mathrm{P}$ & SPQMLT 03 & $1967 / 68$ & $77^{\circ} 16^{\prime} \mathrm{S}$ & $14^{\circ} 25^{\prime} \mathrm{E}$ & $1955-68$ & 45 & Total $\beta$ & Picciotto and others (1971) \\
\hline & SPQML_09 & $\mathrm{P}$ & SPQMLT 03 & $1967 / 68$ & $76^{\circ} 50^{\prime} \mathrm{S}$ & $11^{\circ} 53^{\prime} \mathrm{E}$ & 1955-68 & 52 & Total $\beta$ & Picciotto and others (1971) \\
\hline & SPQML_10 & $\mathrm{P}$ & SPQMLT 03 & $1967 / 68$ & $76^{\circ} 22^{\prime} \mathrm{S}$ & $09^{\circ} 32^{\prime} \mathrm{E}$ & $1955-68$ & 45 & Total $\beta$ & Picciotto and others (1971) \\
\hline & SPQML_11 & $\mathrm{P}$ & SPQMLT 03 & $1967 / 68$ & $75^{\circ} 56^{\prime} \mathrm{S}$ & $07^{\circ} 13^{\prime} \mathrm{E}$ & $1955-68$ & 51 & Total $\beta$ & Picciotto and others (1971) \\
\hline & SPQML_12 & $\mathrm{P}$ & SPQMLT 03 & $1967 / 68$ & $76^{\circ} 17^{\prime} \mathrm{S}$ & $05^{\circ} 48^{\prime} \mathrm{E}$ & 1955-68 & 47 & Total $\beta$ & Picciotto and others (1971) \\
\hline & SPQML_13 & $\mathrm{P}$ & SPQMLT 03 & $1967 / 68$ & $76^{\circ} 38^{\prime} \mathrm{S}$ & $04^{\circ} 16^{\prime} \mathrm{E}$ & 1955-68 & 51 & Total $\beta$ & Picciotto and others (1971) \\
\hline & SPQML_14 & $\mathrm{P}$ & SPQMLT 03 & $1967 / 68$ & $77^{\circ} 10^{\prime} \mathrm{S}$ & $01^{\circ} 46^{\prime} \mathrm{E}$ & $1955-68$ & 43 & Total $\beta$ & Picciotto and others (1971) \\
\hline & SPQML_15 & $\mathrm{P}$ & SPQMLT 03 & $1967 / 68$ & $77^{\circ} 30^{\prime} \mathrm{S}$ & $00^{\circ} 05^{\prime} \mathrm{E}$ & 1955-68 & 42 & Total $\beta$ & Picciotto and others (1971) \\
\hline & SPQML_16 & $\mathrm{P}$ & SPQMLT 03 & $1967 / 68$ & $77^{\circ} 53^{\prime} \mathrm{S}$ & $01^{\circ} 55^{\prime} \mathrm{W}$ & 1955-68 & 56 & Total $\beta$ & Picciotto and others (1971) \\
\hline & SPQML_17 & $\mathrm{P}$ & SPQMLT 03 & $1967 / 68$ & $78^{\circ} 16^{\prime} \mathrm{S}$ & $04^{\circ} 01^{\prime} \mathrm{W}$ & 1955-68 & 52 & Total $\beta$ & Picciotto and others (1971) \\
\hline y & SPQML_18 & $\mathrm{P}$ & SPQMLT 03 & $1967 / 68$ & $78^{\circ} 42^{\prime} \mathrm{S}$ & $06^{\circ} 52^{\prime} \mathrm{W}$ & 1955-68 & 45 & Total $\beta$ & Picciotto and others (1971) \\
\hline y & B04 & $\mathrm{C}$ & AWI & $1981 / 82$ & $70^{\circ} 37^{\prime} \mathrm{S}$ & $8^{\circ} 22^{\prime} \mathrm{W}$ & $1892-81$ & 353 & $\delta^{18} \mathrm{O}, 3 \mathrm{H}$ & Schlosser and others (1999) \\
\hline & FBKM002 & C & AWI & $1986 / 87$ & $70^{\circ} 36^{\prime} \mathrm{S}$ & $8^{\circ} 22^{\prime} \mathrm{W}$ & $1972-86$ & 335 & $\delta^{18} \mathrm{O}, \mathrm{ECM}, 3 \mathrm{H}$ & This paper \\
\hline y & FBKM40 & $\mathrm{C}$ & AWI & $1986 / 87$ & $70^{\circ} 57^{\prime} \mathrm{S}$ & $08^{\circ} 31^{\prime} \mathrm{W}$ & $1971-86$ & 294 & $\delta^{18} \mathrm{O}, \mathrm{ECM}, 3 \mathrm{H}$ & Oerter and others (1999) \\
\hline y & B12 & $\mathrm{C}$ & AWI & 1986/87 & $71^{\circ} 14^{\prime} \mathrm{S}$ & $08^{\circ} 32^{\prime} \mathrm{W}$ & $1961-86$ & 228 & $\delta^{18} \mathrm{O}, \mathrm{ECM}, 3 \mathrm{H}$ & Oerter and others (1999) \\
\hline & FBKM70-W & $\mathrm{C}$ & AWI & $1986 / 87$ & $71^{\circ} 15^{\prime} \mathrm{S}$ & $08^{\circ} 39^{\prime} \mathrm{W}$ & 1979-86 & 295 & $\delta^{18} \mathrm{O}, \mathrm{ECM}, 3 \mathrm{H}$ & This paper \\
\hline y & FBKM90 & $\mathrm{C}$ & AWI & $1986 / 87$ & $71^{\circ} 24^{\prime} \mathrm{S}$ & $08^{\circ} 21^{\prime} \mathrm{W}$ & 1969-86 & 266 & $\delta^{18} \mathrm{O}, \mathrm{ECM}, 3 \mathrm{H}$ & Oerter and others (1999) \\
\hline & SSKM125 & $\mathrm{P}$ & AWI & 1986/87 & $71^{\circ} 41^{\prime} \mathrm{S}$ & $08^{\circ} 30^{\prime} \mathrm{W}$ & 1982-86 & 205 & $\delta^{18} \mathrm{O}, \mathrm{ECM}, 3 \mathrm{H}$ & Oerter and others (1999) \\
\hline y & FBKM143 & C & AWI & $1986 / 87$ & $71^{\circ} 50^{\prime} \mathrm{S}$ & $08^{\circ} 37^{\prime} \mathrm{W}$ & $1972-86$ & 229 & $\delta^{18} \mathrm{O}, \mathrm{ECM}, 3 \mathrm{H}$ & Oerter and others (1999) \\
\hline y & FBKM160 & $\mathrm{C}$ & AWI & $1986 / 87$ & $71^{\circ} 59^{\prime} \mathrm{S}$ & $08^{\circ} 44^{\prime} \mathrm{W}$ & 1969-86 & 277 & $\delta^{18} \mathrm{O}, \mathrm{ECM}, 3 \mathrm{H}$ & Oerter and others (1999) \\
\hline y & FBKM180 & C & AWI & $1986 / 87$ & $72^{\circ} 10^{\prime} \mathrm{S}$ & $08^{\circ} 50^{\prime} \mathrm{W}$ & $1973-86$ & 364 & $\delta^{18} \mathrm{O}, \mathrm{ECM}, 3 \mathrm{H}$ & Oerter and others (1999) \\
\hline y & B10, B11 & $\mathrm{C}$ & AWI & 1986/87 & $72^{\circ} 30^{\prime} \mathrm{S}$ & $09^{\circ} 06^{\prime} \mathrm{W}$ & 1970-86 & 53 & $\delta^{18} \mathrm{O}, \mathrm{ECM}, 3 \mathrm{H}$ & Oerter and others (1999) \\
\hline y & FBKM270 & $\mathrm{C}$ & AWI & $1986 / 87$ & $72^{\circ} 56^{\prime} \mathrm{S}$ & $09^{\circ} 41^{\prime} \mathrm{W}$ & 1970-86 & 46 & $\delta^{18} \mathrm{O}, \mathrm{ECM}, 3 \mathrm{H}$ & Oerter and others (1999) \\
\hline$y$ & BAS_CLA & C & BAS & 1986/87 & $77^{\circ} 34^{\prime} \mathrm{S}$ & $25^{\circ} 22^{\prime} \mathrm{W}$ & 1964-86 & 56 & Total $\beta$ & Wolff and Suttie (1994) \\
\hline y & BAS_H1 & $\mathrm{C}$ & BAS & $1987 / 88$ & $77^{\circ} 02^{\prime} \mathrm{S}$ & $22^{\circ} 32^{\prime} \mathrm{W}$ & $1964-87$ & 155 & NSS, volc. horiz. & Mulvaney and Wolff (1993) \\
\hline y & SW89_A & C & SWEDARP & 1988/89 & $72^{\circ} 39^{\prime} \mathrm{S}$ & $16^{\circ} 39^{\prime} \mathrm{W}$ & $1976-88$ & 364 & $\delta^{18} \mathrm{O}$ & Isaksson and Karlén (1994) \\
\hline y & SW89_C & $\mathrm{C}$ & SWEDARP & $1988 / 89$ & $72^{\circ} 46^{\prime} \mathrm{S}$ & $14^{\circ} 35^{\prime} \mathrm{W}$ & $1976-88$ & 415 & $\delta^{18} \mathrm{O}$ & Isaksson and Karlén (1994) \\
\hline y & SW89_D & C & SWEDARP & 1988/89 & $73^{\circ} 27^{\prime} \mathrm{S}$ & $12^{\circ} 33^{\prime} \mathrm{W}$ & $1976-88$ & 330 & $\delta^{18} \mathrm{O}$ & Isaksson and Karlén (1994) \\
\hline & SW89_E & $\mathrm{C}$ & SWEDARP & 1988/89 & $73^{\circ} 36^{\prime} \mathrm{S}$ & $12^{\circ} 26^{\prime} \mathrm{W}$ & $1976-88$ & 311 & $\delta^{18} \mathrm{O}$ & Isaksson and Karlén (1994) \\
\hline$y$ & SW89_F & C & SWEDARP & $1988 / 89$ & $73^{\circ} 49^{\prime} \mathrm{S}$ & $12^{\circ} 13^{\prime} \mathrm{W}$ & $1976-88$ & 217 & $\delta^{18} \mathrm{O}$ & Isaksson and Karlén (1994) \\
\hline y & SW89_G & C & SWEDARP & $1988 / 89$ & $74^{\circ} 01^{\prime} \mathrm{S}$ & $12^{\circ} 01^{\prime} \mathrm{W}$ & $1976-88$ & 276 & $\delta^{18} \mathrm{O}$ & Isaksson and Karlén (1994) \\
\hline y & SW89_H & $\mathrm{C}$ & SWEDARP & $1988 / 89$ & $74^{\circ} 21^{\prime} \mathrm{S}$ & $11^{\circ} 43^{\prime} \mathrm{W}$ & $1976-88$ & 329 & $\delta^{18} \mathrm{O}$ & Isaksson and Karlén (1994) \\
\hline$y$ & SW89_ & $\mathrm{C}$ & SWEDARP & 1988/89 & $75^{\circ} 05^{\prime} \mathrm{S}$ & $09^{\circ} 32^{\prime} \mathrm{W}$ & 1955-88 & 104 & Total $\beta$ & Isaksson and Karlén (1994) \\
\hline y & SW92_E & $\mathrm{C}$ & SWEDARP & 1991/92 & $73^{\circ} 36^{\prime} \mathrm{S}$ & $12^{\circ} 26^{\prime} \mathrm{W}$ & 1932-91 & 324 & $\delta^{18} \mathrm{O}, \mathrm{ECM}$ & Isaksson and others (1996) \\
\hline y & SW_EPCIA & $\mathrm{C}$ & SWEDARP & $1991 / 92$ & $75^{\circ} 00^{\prime} \mathrm{S}$ & $02^{\circ} 00^{\prime} \mathrm{E}$ & 1865-91 & 77 & $\begin{array}{l}\mathrm{CD} \text { (sodium, nitrate), } \\
\text { volc. horiz. }\end{array}$ & Isaksson and others (1996) \\
\hline$y$ & SW92_1 & C & SWEDARP & 1991/92 & $74^{\circ} 10^{\prime} \mathrm{S}$ & $00^{\circ} 22^{\prime} \mathrm{E}$ & 1965-93 & 116 & Total $\beta$ & This paper \\
\hline y & SW92_2 & $\mathrm{C}$ & SWEDARP & $1991 / 92$ & $76^{\circ} 19^{\prime} \mathrm{S}$ & $06^{\circ} 05^{\prime} \mathrm{W}$ & 1955-93 & 71 & Total $\beta$ & This paper \\
\hline y & Jut_A & C & NARE & 1992/93 & $72^{\circ} 17^{\prime} \mathrm{S}$ & $01^{\circ} 42^{\prime} \mathrm{W}$ & 1976-93 & 491 & $\delta^{18} \mathrm{O}$ & Melvold (1999) \\
\hline y & Jut_B & $\mathrm{C}$ & NARE & $1992 / 93$ & $72^{\circ} 08^{\prime} \mathrm{S}$ & $01^{\circ} 46^{\prime} \mathrm{W}$ & 1976-93 & 487 & $\delta^{18} \mathrm{O}$ & Melvold (1999) \\
\hline y & Jut_C & $\mathrm{C}$ & NARE & 1992/93 & $72^{\circ} 16^{\prime} \mathrm{S}$ & $01^{\circ} 16^{\prime} \mathrm{W}$ & $1976-93$ & 456 & $\delta^{18} \mathrm{O}$ & Melvold (1999) \\
\hline y & Jut_D & $\mathrm{C}$ & NARE & $1992 / 93$ & $72^{\circ} 31^{\prime} \mathrm{S}$ & $01^{\circ} 46^{\prime} \mathrm{W}$ & $1976-93$ & 491 & $\delta^{18} \mathrm{O}$ & Melvold (1999) \\
\hline y & Jut_E & $\mathrm{C}$ & NARE & $1992 / 93$ & $72^{\circ} 59^{\prime} \mathrm{S}$ & $01^{\circ} 08^{\prime} \mathrm{W}$ & 1965-93 & 50 & Total $\beta$ & Melvold and others (1998) \\
\hline y & Jut_F & $\mathrm{C}$ & NARE & 1992/93 & $73^{\circ} 06^{\prime} \mathrm{S}$ & $00^{\circ} 28^{\prime} \mathrm{W}$ & 1965-93 & 120 & Total $\beta$ & Melvold and others (1998) \\
\hline y & Jut_H & $\mathrm{C}$ & NARE & $1992 / 93$ & $70^{\circ} 30^{\prime} \mathrm{S}$ & $02^{\circ} 28^{\prime} \mathrm{W}$ & 1976-93 & 451 & $\delta^{18} \mathrm{O}$, total $\beta$ & Melvold (1999) \\
\hline y & Jut_I & C & NARE & 1992/93 & $71^{\circ} 31^{\prime} \mathrm{S}$ & $01^{\circ} 11^{\prime} \mathrm{E}$ & 1965-93 & 60 & Total $\beta$ & Melvold and others (1998) \\
\hline y & Jut_J & C & NARE & $1992 / 93$ & $72^{\circ} 13^{\prime} \mathrm{S}$ & $00^{\circ} 43^{\prime} \mathrm{W}$ & 1976-93 & 320 & $\delta^{18} \mathrm{O}$, total $\beta$ & Melvold (1999) \\
\hline y & Jut_K & $\mathrm{C}$ & NARE & 1992/93 & $70^{\circ} 45^{\prime} \mathrm{S}$ & $00^{\circ} 00^{\prime} \mathrm{E}$ & 1976-93 & 253 & $\delta^{18} \mathrm{O}$, total $\beta$ & Melvold (1999) \\
\hline y & Jut_L & C & NARE & $1992 / 93$ & $70^{\circ} 56^{\prime} \mathrm{S}$ & $00^{\circ} 13^{\prime} \mathrm{E}$ & 1976-93 & 244 & $\delta^{18} \mathrm{O}$, total $\beta$ & Melvold (1999) \\
\hline y & Jut_M & $\mathrm{C}$ & NARE & $1992 / 93$ & $70^{\circ} 25^{\prime} \mathrm{S}$ & $00^{\circ} 00^{\prime} \mathrm{W}$ & 1984-93 & 371 & $\delta^{18} \mathrm{O}$, total $\beta$ & Melvold (1999) \\
\hline & SW93_1 & $P$ & SWEDARP & 1993/94 & $73^{\circ} 28^{\prime} \mathrm{S}$ & $12^{\circ} 34^{\prime} \mathrm{W}$ & 1991-93 & 280 & $\mathrm{CD}\left(8\right.$ ions, $\left.\delta^{18} \mathrm{O}\right)$ & Stenberg and others (1998) \\
\hline y & SW93_2 & $\mathrm{P}$ & SWEDARP & 1993/94 & $74^{\circ} 58^{\prime} \mathrm{S}$ & $11^{\circ} 48^{\prime} \mathrm{W}$ & 1988-93 & 120 & $\mathrm{CD}\left(8\right.$ ions, $\left.\delta^{18} \mathrm{O}\right)$ & Stenberg and others (1998) \\
\hline y & SW93_3 & $\mathrm{P}$ & SWEDARP & 1993/94 & $78^{\circ} 02^{\prime} \mathrm{S}$ & $10^{\circ} 59^{\prime} \mathrm{W}$ & 1986-93 & 90 & $\mathrm{CD}\left(8\right.$ ions, $\left.\delta^{18} \mathrm{O}\right)$ & Stenberg and others (1998) \\
\hline y & SW93_4 & $P$ & SWEDARP & 1993/94 & $75^{\circ} 33^{\prime} \mathrm{S}$ & $09^{\circ} 46^{\prime} \mathrm{W}$ & 1984-93 & 70 & $\mathrm{CD}\left(8\right.$ ions, $\left.\delta^{18} \mathrm{O}\right)$ & Stenberg and others (1998) \\
\hline
\end{tabular}


Table 5. (continued)

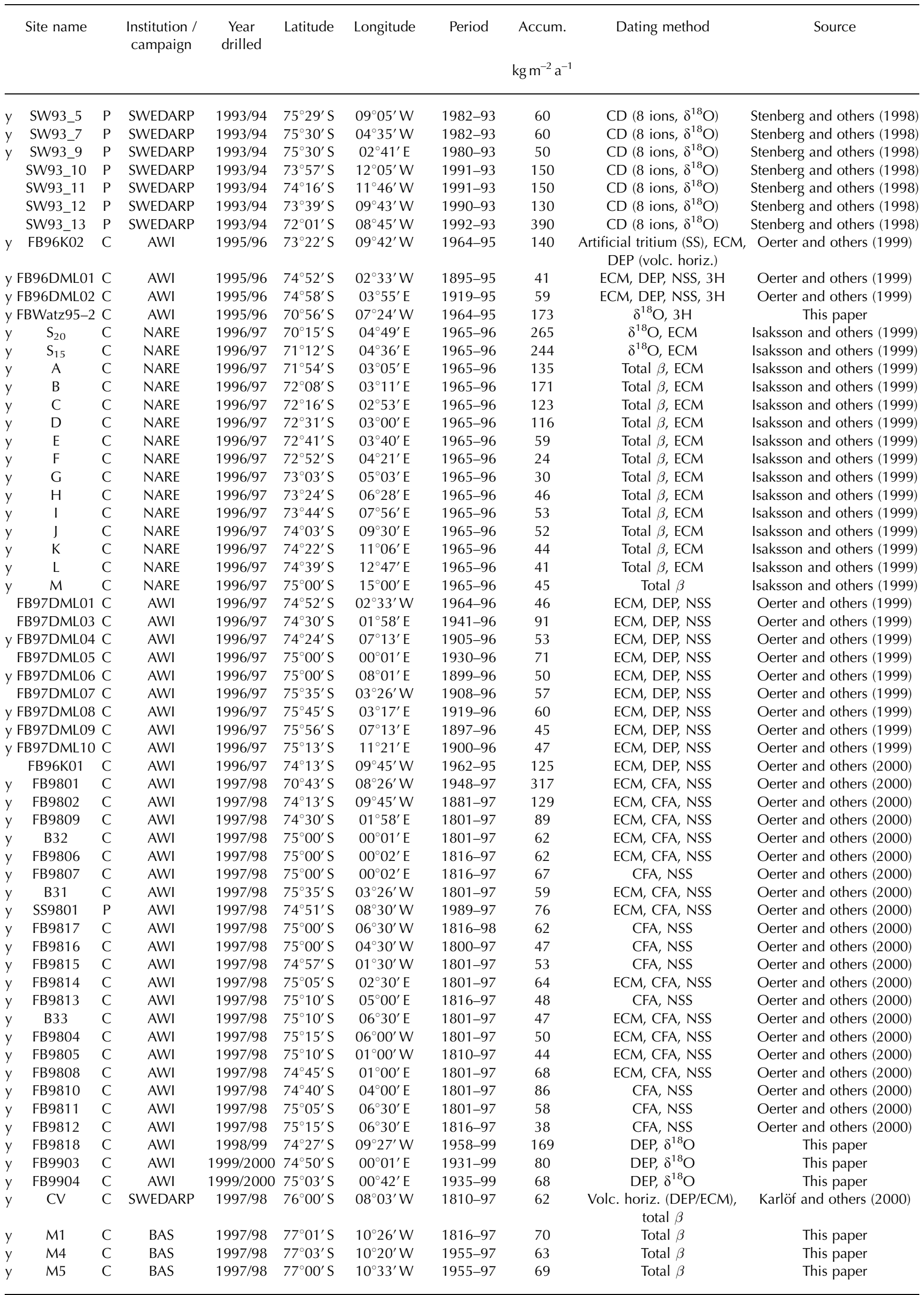


Table 5. (continued)

\begin{tabular}{|c|c|c|c|c|c|c|c|c|c|c|}
\hline \multicolumn{3}{|c|}{ Site name } & \multirow{2}{*}{$\begin{array}{l}\text { Institution / } \\
\text { campaign }\end{array}$} & \multirow{2}{*}{$\begin{array}{c}\text { Year } \\
\text { drilled }\end{array}$} & \multirow[t]{2}{*}{ Latitude } & \multirow[t]{2}{*}{ Longitude } & \multirow[t]{2}{*}{ Period } & Accum. & \multirow[t]{2}{*}{ Dating method } & \multirow[t]{2}{*}{ Source } \\
\hline & & & & & & & & $\mathrm{kg} \mathrm{m}^{-2} \mathrm{a}^{-1}$ & & \\
\hline y & M6 & $\mathrm{C}$ & BAS & $1997 / 98$ & $77^{\circ} 01^{\prime} \mathrm{S}$ & $06^{\circ} 40^{\prime} \mathrm{W}$ & 1955-97 & 68 & Total $\beta$ & This paper \\
\hline$y$ & BAS-Depot & C & BAS & $1997 / 98$ & $77^{\circ} 02^{\prime} \mathrm{S}$ & $10^{\circ} 30^{\prime} \mathrm{W}$ & 965-98 & 71 & DEP (volc. horiz.) & Hofstede and others (2004) \\
\hline & M150 & C & NARE & $2000 / 01$ & $75^{\circ} 00^{\prime} \mathrm{S}$ & $15^{\circ} 00^{\prime} \mathrm{E}$ & $965-98$ & 43 & DEP (volc. horiz.) & Hofstede and others (2004) \\
\hline$y$ & FB0501 & $\mathrm{C}$ & AWI & $2004 / 05$ & $74^{\circ} 09^{\prime} \mathrm{S}$ & $09^{\circ} 41^{\prime} \mathrm{W}$ & 1975-2004 & 183 & $\delta^{18} \mathrm{O}, \mathrm{DEP}$ & This paper \\
\hline
\end{tabular}

Notes: $3 \mathrm{H}$ : tritium content; CD: chemical data; CFA: continuous flow analysis; DEP: dielectric profiling; ECM: electrical conductivity method; NSS: non-seasalt sulphate (volcanic eruptions); $\delta^{18} \mathrm{O}$ : oxygen-isotope stratigraphy; SS: sea salt; volc. horiz. volcanic horizons.

MS received 14 May 2006 and accepted in revised form 21 February 2007 